\title{
Technological and sensory characteristics of hamburgers added with chia seed as fat replacer
}

\author{
Marielle Maria de Oliveira Paula ${ }^{*}$ (D) Juliana Resende Gonçalves Silva ${ }^{2}$ (D) \\ Karoliny Lamas de Oliveira ${ }^{2}$ (D) Armando Abel Massingue ${ }^{3}$ (iD) Eduardo Mendes Ramos $^{1}$ (iD \\ Augusto Aloísio Benevenuto Júnior ${ }^{2}$ (D) Maurício Henriques Louzada Silva ${ }^{2}$ iD \\ Vanessa Riani Olmi Silva² iD
}

'Departamento de Ciência dos Alimentos, Universidade Federal de Lavras (UFLA), 37200-000, Lavras, MG, Brasil. E-mail: maricta12@hotmail.com. ${ }^{*}$ Corresponding author.

${ }^{2}$ Instituto Federal de Educação Ciência e Tecnologia do Sudeste de Minas Gerais, Rio Pomba, MG, Brasil. ${ }^{3}$ Escola Superior de Desenvolvimento Rural, Universidade Eduardo Mondlane (UEM), Vilankulo, Mozambique.

ABSTRACT: In order to improve nutritional and functional quality, chicken burgers were made with different amounts of chia seed (0, 2, 4 and 8\%) as pork fat replacers and evaluated for the microbiological, technological and sensorial characteristics. The proximate composition and the microbiological characteristics of raw burgers were in accordance with Brazilian legislation. Higher additions of chia increased the amount of dietary fiber (up to 1.46\%) and carbohydrate in the products and reduced the fat content by up to 29\%. The addition of chia seed reduced the $a^{*}$ values and increased the $h^{*}$ values of the raw burgers and reduced the tenderness and degree of lipid oxidation in the cooked burgers. Lower sensory taste scores and overall acceptance were conferred on products with higher chia addition; although, the degree of acceptance of the products was high. Results of this study highlighted the potential use of chia seed in the elaboration of low fat and enriched dietary fiber burgers. Key words: Salvia hispanica, dietary fiber, lipid oxidation, shear force, check-all-that-applies analysis.

Características tecnológicas e sensoriais de hambúrgueres adicionados de semente de chia como substituta de gordura

RESUMO: No intuito de melhorar a qualidade nutricional e funcional, hambúrgueres de frango foram elaborados com diferentes quantidades de semente de chia (0,2, 4 e 8\%) em substituição ao toucinho e avaliados quanto às características microbiológicas, tecnológicas e sensoriais. A composição centesimal e as características microbiológicas dos hambúrgueres crus estavam de acordo com o preconizado pela legislação Brasileira. Maiores adições de chia aumentaram a quantidade de fibra dietética (até 1,46\%) e de carboidrato nos produtos e reduziu os valores de gordura em até 29\%. A adição de semente de chia reduziu os valores de a* e aumentou os valores de $h^{*}$ da cor dos hambúrgueres crus e reduziu a maciez e o grau de oxidação lipídica nos hambúrgueres cozidos. Menores notas sensoriais de sabor e a aceitação global foram conferidas aos produtos com maior adição de chia, embora o grau de aceitação dos produtos tenha sido elevado. Os resultados deste estudo destacam o potencial de uso da semente de chia na elaboração de hambúrgueres com baixo teor de gordura e enriquecidos de fibra dietética. Palavras-chave: Salvia hispanica L., fibra dietética, oxidação lipídica, análise CATA.

\section{INTRODUCTION}

Meat and meat products are considered harmful for health due to their high saturated fatty acid and cholesterol content (YADAV et al., 2018). However, fat presents an important role in meat products, being directly related to some sensorial properties, such as juiciness, texture and flavor, and technological aspects, like cooking loss, emulsion stability, water holding capacity and rheological properties (SELANI et al., 2016). A large intake of saturated fat can lead to the occurrence of chronic diseases (DING et al., 2018). Therefore, the growing demand for healthier products is stimulating the development of meat products with reduced fat.

In this context, due to its practicality and its popular reach, the restructured meat products like burgers were a compelling choice for fat reduction (RODRÍGUEZ-CARPENA et al., 2012). For the modern food industries, reduction of fat in burger processing represents a challenge, since it must have good acceptance in the market and compete with the traditional ones that had highfat content. Even knowing the risks of excessive 
consumption of fats, there is a preference of the consumers for the fat in this type of product, since it's responsible for the juiciness, as well as flavor and aroma (MILLER et al., 1993).

Fiber is one of the most common functional ingredients for functional foods and has been used as the fat replacer. Its use is interesting since in addition to its capacity to improve cooking yield, reduce formulation costs and enhance texture in meat products,improving nutritional value due to the considerable evidence from epidemiological, clinical and biochemical studies that dietary fiber has a positive influence on human health (SELANI et al., 2016; LÓPEZ-VARGAS et al., 2014). Among the different sources of fiber with a favorable appeal to be used in a healthy diet, chia seeds (Salvia hispanica L.) have gained attention as a food ingredient. Seeds of chia have high dietary fiber content that has become an important component in the daily diet (REYESCAUDILLO et al., 2008; DING et al., 2018; CAPITANI et al., 2012).

Further, chia seed dietary get the most by its namely popularity as the main source of hydration fiber compared to other sources of fiber, with higher water absorption and absorption of organic molecules with high emulsifying activity (ALFREDO et al., 2009; DING et al., 2018). Moreover, it has good nutritional characteristics, such as low digestibility, high protein and unsaturated omega-3 fatty acids contents (FERNANDES \& SALAS-MELLADO, 2017) and its antioxidant and functional capacity (MARINELI et al., 2014; MOHD ALI et al., 2012; SARGI et al., 2014).

Chia seeds functionality has been expected and applied by the food industry, since when a chia seed is immersed in water it forms a gel called a chia mucilage as a thickener, gel-forming and chelating agent (CAPITANI et al., 2012; FERNANDES \& SALAS-MELLADO, 2017).

In general, an intake of dietary fiber has many health beneficial effects. Some of them include reduction of cholesterolemia, modification of the glycemic and insulinemic responses, changes in intestinal function and antioxidant activity. Dietary fiber has the same technological properties as a fatbinding, gel-forming, chelating and texturizing agent (REYES-CAUDILLO et al., 2008).

Although, chia is a potential ingredient in healthy and dietetic foods, to our knowledge, there are fewer published data using chia seeds for meat products production (SCAPIN et al., 2015; DING et al., 2018). Therefore, the aim of the present paper was to develop a fiber-enriched chicken burger using chia seeds as pork back fat replacer and study the effect of fiber incorporation on physicochemical and sensory characteristics of burgers.

\section{MATERIAL AND METHODS}

Fresh poultrybreastand thighmeat(without skin), pork back fat and chia seed were obtained from the local market. Chia seeds were previously sterilized in UV lighting for 15 minutes. The burgers were produced and analyzed at the laboratories of the Food Science and Technology Department (DCTA) of the Federal Institute of Education, Science and Technology of the Southeast of Minas Gerais (IF SUDESTE MG). The 2-thiobarbituric acid reactive substances (TBARS) and texture analyses were conducted at the Laboratory of Technology of Meat and Meat Products (LabCarnes) of the Food Science Department (DCA) of the Universidade Federal de Lavras (UFLA).

Poultry meat and pork back fat were separately ground (CAF-model 22STB, São Paulo, Brazil) using a $5 \mathrm{~mm}$ plate and then ground poultry meat was divided into 4 treatments. The first treatment was used as control (CONT) and its fat content was adjusted to $18 \%$ by the addition of pork back fat. All the poultry ground meat was used for the formulation: $76 \%$ (48\% thigh and $28 \%$ breast), $18 \%$ pork backfat, $2.0 \%$ sodium chloride, $0.3 \%$ sodium erythorbate, $0.3 \%$ sodium polyphosphate, $3.1 \%$ spices mix (minced garlic, onion, rosemary, black pepper, and curry powder), and $0.3 \%$ monosodium glutamate. Three treatments with chia addition at $2 \%(\mathrm{CH} 2), 4 \%(\mathrm{CH} 4)$, or $8 \%(\mathrm{CH} 8)$, respectively, as pork backfat replacer into the formulation of burgers were also produced. Other ingredients were used in similar concentration as in control. After burger batter forming, about 80 $\mathrm{g}$ portions were manually shaped using an inox burger maker machine, to give the dimensions of $10 \mathrm{~cm}$ diameter and approximately $1 \mathrm{~cm}$ thickness. The raw burgers were then placed in polyethylene packages and stored per 24 hours under $-18{ }^{\circ} \mathrm{C}$ until further analysis and cooking treatment.

Burgers samples of each treatment were individually weighed and grilled in a preheated $\left(150{ }^{\circ} \mathrm{C}\right.$ ) clam-shell grill (George Foreman, Super Jumbo, GBZ31SB, NY, USA) for 2 minutes for each side to achieve a core temperature of $71^{\circ} \mathrm{C}$ monitored with help of thermocouple probe (MT525, Minipa industry Co., Ltd., São Paulo, Brazil). Samples were cooled at room temperature $\left(25^{\circ} \mathrm{C}\right)$ per 15 minutes before reweighing for cooking loss determination. 
In order to verify the compliance with the microbiological limits required by Brazilian legislation for raw chilled or frozen meat products (ANVISA, 2001), the raw burgers were evaluated for thermotolerant coliforms (most probable number, MPN/g sample), Staphylococcus coagulase positive (colony forming unit, CFU/g sample) and Salmonella, by the techniques described by the American Public Health Association (DOWNES AND ITO, 2001).

The physicochemical analysis analyses were performed in raw burgers. Moisture, ash, lipid (Soxhlet), and protein (Kjeldahl, $\mathrm{N} \times 6.25)$ were determined according to AOAC (2012), and the available carbohydrates were calculated by difference of total percentage and sum of all other components, as follow: \% Carbohydrates $=100 \%-(\%$ moisture $+\%$ protein $+\%$ fat $+\%$ ash $)$. Dietary fiber content was quantified according to the enzyme-gravimetric method described by the Instituto Adolfo Lutz (IAL, 2008). Color of raw burgers was also determined using a colorimeter (Konica Minolta, Chroma Meter, CR-10, NJ, USA) with a measurement area of $8 \mathrm{~mm}$ in diameter, observation angle of $10^{\circ}$ and illuminant D65. Five measurements were taken from each sample. Lightness $\left(L^{*}\right)$, redness $\left(a^{*}\right)$ and yellowness $\left(b^{*}\right)$ were recorded. Chroma $\left(C^{*}\right)$ and hue angle $\left(h^{o}\right.$, graus) were calculated as: $C^{*}=\left(a^{* 2}+b^{* 2}\right)^{1 / 2}$; and $h^{o}=$ $\tan ^{-1}\left(b^{*} / a^{*}\right)$. Higher $C^{*}$ values suggested more vivid color; and $h^{\circ}$ values near 0 are red and near $90^{\circ}$ are yellow (RAMOS AND GOMIDE, 2017).

For grilled burgers, $\mathrm{pH}$, water activity (Aw), cooking loss, reduction of diameter, lipid oxidation and shear force were evaluated. The $\mathrm{pH}$ of the products was measured using a digital $\mathrm{pH}$ meter (Digimed model DM20, São Paulo, SP, Brazil) after homogenization of $10 \mathrm{~g}$ of sample in $100 \mathrm{~mL}$ of distilled water. The $\mathrm{pH}$ meter calibrated with three different standard solutions (4.00 and 7.02 $\mathrm{pH}$ buffers) at a temperature of $20{ }^{\circ} \mathrm{C} \pm 1{ }^{\circ} \mathrm{C}$. For water activity (Aw), samples were ground and direct analyzed in an AquaLab CX2 (Decagon Devices, Inc., Pullman, WA, USA) hygrometer. Diameter and thickness of the raw and cooked burgers were recorded using a digital caliper rule and calculated using the following expression: Reduction in diameter $(\%)=[$ (raw chicken burger diameter grilled chicken burger diameter)/raw chicken burger diameter] $\times 100$. Cooking loss was determined by calculating the weight differences before and after grilling as follows: Cooking loss $(\%)=[$ (weight of raw chicken burger $(\mathrm{g})$ - weight of grilled chicken burger $(\mathrm{g}))$ /weight of raw chicken burger $(\mathrm{g})] \times 100$.
Level of lipid oxidation in the products was assessed by measuring the TBARS proposed by RAHARJO et al., (1992), with modifications described by CARDOSO et al., (2016). Shear force was determined using a Texture Analyzer TA-XT (Stable Micro Systems, Godalming, United Kingdom). All determinations were made in triplicate.

Shear force measurements were conducted in a cuboid $(1.0 \mathrm{~cm} \times 1.0 \mathrm{~cm}$ square cross-section) cores according to the Warner-Bratzler square Shear Force (WBsSF) protocol, as described by SILVA et al., (2015). Five cores were obtained from each burger and sheared in a crosshead speed test of $3.33 \mathrm{~mm} / \mathrm{s}$ by a Warner-Bratzler blade coupled to a TA.XT plus texturometer (Stable Micro Systems Ltd., Godalming, Surrey, UK). The average peak shear force (N) of the five cores was used for the statistical analyses.

Sensory analysis was fulfilled behind the National Research Ethics System (SISNEP, Brazil) permission under protocol CAAE 35793414.5.0000.5588. To describe the sensory characterization of each product formulated, the check-all-that-apply (CATA) questions were used as proposed by JORGE et al., (2015) and MASSINGUE et al., (2018). Twenty untrained participants were firstly met to define the CATA terms. They were randomly recruited at IF SUDESTE MG and consisted of undergraduate and graduate students, with ages ranging from 18 to 30 years old. All participants declared to be frequent consumers (more than twice per week) of burgers. Samples were presented in a single testing session (Repertory Grid technique), and judges used an open-ended question to establish the appropriate terms for describing their appearance, flavor and texture. The most mentioned terms for each attribute were chosen to compose the CATA questions (Table 1).

In the second stage, 50 untrained participants (17 males and 33 females) with ages

Table 1 - Terms surveyed for check-all-that-applies (CATA) questions of each sensory attribute.

\begin{tabular}{lcc}
\hline Appearance & Flavor & Texture \\
\hline Yellowish pale color & Pleasant flavor & Integrate texture \\
\hline Brown color & Cooked flavor & Grain texture \\
\hline Uniform appearance & Caramel flavor & Fibrous \\
& Bland flavor & Crispy \\
& Salty & Juicy \\
& Seasoned & Tenderness \\
\hline & Bitter after taste & \\
\hline
\end{tabular}


ranging from 18 to 44 years old were also randomly recruited at IF SUDESTE MG to evaluate the samples. Sensory analysis was performed in a single testing session conducted in individual cabins with white light. A 3-digit code was used to label the samples offered to the panelist. Samples were presented randomly and balanced following a monadic sequence. Potable water was offered to the panelists for mouth rinsing between sample trials. Samples were evaluate under acceptance test using a hedonic scale of 1 (disliked very much) to 9 (liked very much) for each attribute (flavor, texture and overall impression acceptance). In the same form, the panelists were asked to check all the terms of CATA questions (as previously defined, table 1) that could be appropriate to describe each formulation.

The experiment was conducted in a completely randomized design with three replicates. Data were tested by F-test (ANOVA) and the means were separated using Tukey's test $(P<0.05)$ using the SAS statistical (SAS Institute Inc., Cary, NC, USA) package, version 9.2.

To identify the relationship between the CATA terms selected for each sample, an external preference map (EPM) based in the regression of external descriptors against consumer data (overall impression acceptance in this case) was used. Only the slopes for consumers that provided models with less than $30 \%$ of significance (ELMORE et al., 1999) were plotted on the EPM, being performed in the Senso Maker statistical software (Lavras, Brazil), version 1.5.

\section{RESULTS AND DISCUSSION}

Microbial growth of the raw burgers was not affected $(P>0.05)$ by the addition of chia seeds. The microbial counts of all treatments were $<10^{2}$ $\mathrm{MNP} / \mathrm{g}$ for thermo tolerant coliforms, $<10^{3} \mathrm{CFU} / \mathrm{g}$ for coagulase-positive Staphylococcus and absence of Salmonella in $25 \mathrm{~g}$. All treatments showed counts within the limits $\left(5.0 \times 10^{3} \mathrm{MPN} / \mathrm{g}\right.$ for thermo tolerant coliforms; $5.0 \times 10^{3} \mathrm{CFU} / \mathrm{g}$ for coagulase-positive Staphylococcus; and absence/25 g for Salmonella) established by the Brazilian Health Surveillance Agency (ANVISA, 2001). While extract of chia seeds did not act like an antimicrobial agent (SCAPIN et al., 2015), this result was expected since all steps on processing was observed the hygienic and sanitary practices of production.

The proximate composition of raw chicken burgers and Dietary fiber are shown in table 2. All samples were in accordance with Brazilian legislation (ANVISA, 2001), which establishes a maximum amount of $23 \%$ fat and a minimum amount of $15 \%$ protein. No dilution effects resulting from the chia seeds added to the formulations was observed $(P>0.05)$ for protein, moisture and ash content. These were probably due to the high content of protein (15 to $25 \%)$ and fat $(30 \%)$ of the chia seeds (MOHD ALI et al., 2012), but especially to its high content of carbohydrates (26 to $41 \%$ ), which contributed to the increase $(P<0.05)$ of carbohydrates in the products.

It was observed a significant effect $(P<0.05)$ of chia seeds addition on reduction of fat content (Table 2). The treatment with $8 \%$ chia seeds $(\mathrm{CH} 8)$ resulted in a significant reduction of fat compared to the others. This result is supposed to be due the chia seeds have also high amount of fiber in its composition. Thus, higher amount added chia seeds higher fiber content and lower fat results (MOHD ALI et al., 2012; MARINELI et al., 2014). TREVISAN et al., (2016) observed reduction of $35 \%$ in the fat content for the treatments with $3 \%$ and $6 \%$ of added oat fiber as compared to the control. By the Brazilian law, this treatment could be labeled as "reduced fat" or "light" burger, since it provides more than $25 \%$ fat reduction when compared to the traditional product (ANVISA, 2003). In addition, due to its high (18 to $30 \%$ ) dietary fiber content (MOHD ALI et al., 2012), with predominant soluble fiber (MARINELI et al., 2014), the use of chia seeds allowed incorporating dietary fiber into the product. Brazilian legislation (ANVISA, 2012) requires that each food portion contain at least $2.5 \mathrm{~g}$ or $5.0 \mathrm{~g}$ in order to include the terms "source of dietary fiber" or "high content of dietary fiber", respectively, on the product label. Since the hamburger portion is 80 g (ANVISA, 2003), 3.1\% of dietary fiber should be added to apply this label. Addition chia seeds up to $8 \%$ represent less than a half amount of fiber required for food to be reported as fiber source. Moreover, chia seeds are excellent source of $\omega$-alpha-linolenic acid (an omega-3 fatty acid), contains high levels of polyunsaturated fatty acids (MOHD ALI et al., 2012; SARGI et al., 2014) and their bioactive components promoted health benefit (MARINELI et al., 2014).

The results of cooking loss, reduction in diameter, $\mathrm{pH}$, water activity, TBARS and shear force are shown in table 2. Cooking loss, reduction in diameter after grilling process, $\mathrm{pH}$ and water activity (Aw) were not significantly different $(P>0.05)$ between treatments. In their study, CHOI et al., (2016) observed a significant reduction of cooking loss and reduction diameter when they replaced pork back fat 
Table 2 - Proximate composition, physicochemical and shear force characteristics (mean values \pm standard deviations) of raw and grilled chicken burgers containing chia seeds.

\begin{tabular}{|c|c|c|c|c|c|}
\hline \multirow[t]{2}{*}{ Characteristics } & \multicolumn{4}{|c|}{-----------------------------------------Treatments---------------------------------- } & \multirow[t]{2}{*}{$\operatorname{Pr}>F^{1}$} \\
\hline & CONT & $\mathrm{CH} 2$ & $\mathrm{CH} 4$ & CH8 & \\
\hline \multicolumn{6}{|c|}{--1-- } \\
\hline Fat $(\%)$ & $16.9 \pm 0.5^{a b}$ & $17.3 \pm 0.7^{a}$ & $14.3 \pm 1.1^{b c}$ & $12.0 \pm 0.6^{c}$ & $<0.01$ \\
\hline Protein $(\%)$ & $19.8 \pm 0.7$ & $19.6 \pm 0.3$ & $19.6 \pm 0.6$ & $19.9 \pm 0.4$ & 0.89 \\
\hline Moisture (\%) & $58.7 \pm 1.8$ & $57.2 \pm 0.6$ & $55.7 \pm 1.1$ & $55.3 \pm 1.5$ & 0.98 \\
\hline Ash (\%) & $3.7 \pm 0.4$ & $3.8 \pm 0.2$ & $3.9 \pm 0.4$ & $4.1 \pm 0.6$ & 0.33 \\
\hline Carbohydrates (\%) & $2.8 \pm 0.8^{b c}$ & $2.5 \pm 0.4^{c}$ & $4.2 \pm 1.2^{a b}$ & $7.0 \pm 1.3^{a}$ & 0.03 \\
\hline Dietary fiber (\%) & $0.1 \pm 0.1^{d}$ & $0.4 \pm 0.1^{c}$ & $0.9 \pm 0.1^{b}$ & $1.4 \pm 0.1^{a}$ & $<0.01$ \\
\hline \multicolumn{6}{|c|}{--- } \\
\hline $\mathrm{pH}$ & $6.4 \pm 0.1$ & $6.3 \pm 0.04$ & $6.3 \pm 0.2$ & $6.3 \pm 0.1$ & 0.76 \\
\hline Aw & $0.8 \pm 0.02$ & $0.9 \pm 0.04$ & $0.8 \pm 0.01$ & $0.8 \pm 0.01$ & 0.41 \\
\hline Cooking loss (\%) & $21.3 \pm 3.5$ & $24.1 \pm 4.0$ & $22.2 \pm 3.7$ & $20.4 \pm 3.3$ & 0.65 \\
\hline Reduction in diameter (\%) & $12.6 \pm 1.0$ & $10.6 \pm 4.7$ & $11.2 \pm 3.0$ & $10.8 \pm 1.8$ & 0.84 \\
\hline TBARS (mg MDA/kg) & $2.5 \pm 0.5^{a}$ & $1.4 \pm 0.3^{b}$ & $1.1 \pm 0.1^{b c}$ & $0.8 \pm 0.2^{c}$ & $<0.01$ \\
\hline Shear force $(\mathrm{N})$ & $37.8 \pm 5.5^{c}$ & $46.1 \pm 3.3^{b}$ & $61.9 \pm 5.6^{a}$ & $64.1 \pm 0.6^{a}$ & $<0.01$ \\
\hline
\end{tabular}

$\mathrm{CONT}=$ control; $\mathrm{CH} 2=2 \%$ fat replaced by chia seed; $\mathrm{CH} 4=4 \%$ fat replaced by chia seed; $\mathrm{CH} 8=8 \%$ fat replaced by chia seed.

TBARS, thiobarbituric acid reactive substances; MDA, malonaldehyde.

${ }^{1}$ Significant probabilities $(P<0.05)$ are placed in bold.

${ }^{a-d}$ Means with different superscripts within the same row for each characteristic differ significantly $(P<0.05)$.

level by dietary fiber from Wheat Sprout in reducedfat chicken patties. Therefore, replacement pork back fat with chia seeds up to $8 \%$ resulted in similar cooking loss and reduction in diameter $(21.9 \pm 3.6 \%$ vs. $11.3 \pm 2.6 \%)$ compared with those of the control sample. Both $\mathrm{pH}$ and Aw (6.3 \pm 0.1 vs. $0.8 \pm 0.02)$ values of grilled samples with added chia seeds also placed similar for control. It was expected that increased chia seeds added could cause an increase in Aw and decreasing of $\mathrm{pH}$ (CHOI et al., 2016). A explanation of the results reported this experiment could be related to the fact that there were no differences in protein and moisture of raw samples, and, the addition of chia seeds have provided a small variation in carbohydrates content and greater reduction of fat content due to the increased amounts of chia seeds. In addition, cooking process used in this experiment consisted in a preheated technique (clam-shell grill at $150{ }^{\circ} \mathrm{C}$ ) prior a grilling in a short time (2 minutes), which maybe was efficient to minimize greater differences in weight loss. This was $\mathrm{w}$ expected since $\mathrm{pH}$ values of raw batters are the same. In this scenario, the grilling technique and similar $\mathrm{pH}$ values could be the main reasons to the similar values of diameter and water activity among treatments.

The TBARS test has been widely used to measure lipid oxidation in meat and meat products.
Since heating accelerates oxidative reactions in meat, the oxidation process is strongly enhanced during cooking (ARAÚJO, 2011). The TBARS values of the grilled burgers were dependent on the amount of chia seeds added $(P<0.05)$ : higher additions resulted in lower TBARS values. This means that chia seed retained its antioxidant effect during cooking. High antioxidant activity of chia seeds results from their polyphenols content (MOHD ALI et al., 2012), mainly quercetin, kaempferol and chlorogenic acid (MARINELI et al., 2014; REYES-CAUDILLO et al., 2008). Dietary fibers added to meat products showed a high ability to keep moisture and fat in the meat matrix, increasing cooking yield and reducing burger shrinkage (SELANI et al., 2016; LÓPEZ-VARGAS et al., 2014). Chia seeds had excellent potential as a hydrocolloid, due to its marked swelling capacity and high viscosity in aqueous solution (MOHD ALI et al., 2012). Instead, cooking loss was not different $(P>0.05)$ between treatments, which means that chia seeds additions do not contribute to hold water/fat from burgers during the cooking process and avoid fluid loss. The shear force increasing $(P<0.05)$ due to chia seeds addition was observed in this study. This result could be probably due to the cooking process that allows loosing water and; therefore, has resulted in higher fiber content that could cause 
an increase of the shear press modulus. Higher shear force was observed by YADAV et al., (2018) when $9 \%$ bran level was used in comparison to the control sample, whereas no significant difference was noticed in shear force value of control and dried carrot pomace treated sausage. They also supposed that varied results could be due to that obtained on textural properties of meat products depending on amount and type of fiber added. This approach can be confirmed with the study of TREVISAN et al., (2016), who observed that both the hamburgers with $3 \%$ and $6 \%$ of added oat fiber showed values for hardness, cohesiveness and chewiness similar to those of the control.

Table 3 shows the color characteristics of raw and grilled chicken burgers prepared with different levels of chia seeds. There are significant interactions $(P<0.05)$ between cooking (raw or grilled samples) and treatment (chia seed content) for redness $\left(a^{*}\right)$ and hue angle $\left(\mathrm{CIE} h^{\circ}\right)$. Control samples were reddish (higher CIE $a^{*}$ and lower CIE $h^{o}$ values; figure 1). The chia seeds addition did not alter $(P>0.05)$ both $L^{*}, b^{*}$ and $C^{*}$, but grilling process increased $(P<0.05)$ CIE $L^{*}$ and CIE $b^{*}$ values. A similar result was also reported by TREVISAN et al., (2016) who observed that CIE $b^{*}$ values have increased in grilled chicken burgers when oat fiber was added.

Although, CIE $a^{*}$ value is commonly analyzed individually in meat science literature, Ramos and Gomide (RAMOS AND GOMIDE, 2017) reported that chromaticity indices (CIE $a^{*}$ and CIE $b^{*}$ ) alone do not correctly describe the color of the products, since they are coordinates in a solid color and, together, numerically describe the saturation and hue attributes of the color. Despite the lack of effects on luminosity and color saturation (CIE $C^{*}$ ) of the samples, greater chia seeds additions as fat replacement has resulted in more yellowish (higher

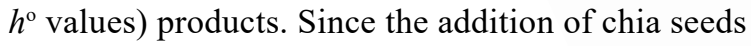
implies in a reduction of fat from the formulation, it was expected that the color of its final product would be darker than control, as observed by SELANI et al., (2016) in fat replacement pineapple fiber in beef burgers. In fact, reduction of CIE $L^{*}$ values with higher additions of chia seeds was observed (Table 2), but this reduction was not significant $(P>0.05)$ due to the great variation observed between samples. This variation was probably due to the presence of chia seeds (or dark color) on the surface of the sample.

All the samples had typical sensory characteristics of burgers based on the Identity and Quality Standards established by the Brazilian legislation (BRASIL, 2000). Overall, the inclusion of chia seeds in burger formulation as a substitute for fat had little effect on the acceptance of the products (Table 4), whose scores were between 7 and 8 ("I fairly liked it" and "I liked it a lot"). The addition of $4 \%$ or $8 \%$ chia seeds resulted in lower $(\mathrm{P}<0.05)$ overall impression acceptance hedonic scores of chicken burger samples. Control and $\mathrm{CH} 2$ burgers samples had same score $(8.1 \pm 1.1)$, while $\mathrm{CH} 4$ and CH8 had also similar (7.6 \pm 1.6$)$ of acceptance. A slight differences $(P<0.05)$ in flavor was also observed, but there are unperceived differences between treatments control, $\mathrm{CH} 2$ and $\mathrm{CH} 4$, or either among all that contain added chia seeds. However, the addition of $2 \%$ chia seed resulted in products with the same sensory acceptance of the control.

For a better understanding of how the sensory attributes were affected by the treatments can be obtained through the external preference map (EPM) from the CATA analysis (Figure 2). The first two main components of the EPM explained

Table 3 - Instrumental color characteristics (mean values \pm standard deviations) of chicken burgers prepared with different levels of chia seeds.

\begin{tabular}{|c|c|c|c|c|c|c|c|c|c|}
\hline \multirow[t]{2}{*}{ Characteristics } & \multicolumn{2}{|c|}{-------Cooking (C)------ } & \multicolumn{4}{|c|}{-----------------------'Treatments (T)---------------------- } & \multicolumn{3}{|c|}{------------ $P r>F^{1}$} \\
\hline & Raw & Grilled & CONT & $\mathrm{CH} 2$ & $\mathrm{CH} 4$ & $\mathrm{CH} 8$ & $\mathrm{C}$ & $\mathrm{T}$ & CxT \\
\hline Lightness (CIE $\left.L^{*}\right)$ & $35.3 \pm 5.6^{b}$ & $45.9 \pm 5.4^{a}$ & $46.0 \pm 7.8^{a}$ & $37.2 \pm 8.5^{b}$ & $38.6 \pm 5.9^{a b}$ & $40.8 \pm 6.8^{a b}$ & $<0.01$ & 0.03 & 0.92 \\
\hline Redness (CIE $\left.a^{*}\right)$ & $5.0 \pm 4.6$ & $4.1 \pm 1.4$ & $7.9 \pm 5.2$ & $2.9 \pm 1.7$ & $3.3 \pm 1.6$ & $4.2 \pm 1.4$ & 0.01 & 0.391 & 0.03 \\
\hline Yellowness $\left(\mathrm{CIE} b^{*}\right)$ & $12.4 \pm 4.5^{b}$ & $16.3 \pm 2.2^{a}$ & $13.8 \pm 3.6$ & $13.4 \pm 4.3$ & $14.5 \pm 5.6$ & $15.6 \pm 2.6$ & 0.03 & 0.78 & 0.81 \\
\hline Chroma (CIE $\left.C^{*}\right)$ & $14.0 \pm 4.8$ & $16.8 \pm 2.4$ & $16.7 \pm 2.5$ & $13.7 \pm 4.5$ & $14.9 \pm 5.6$ & $16.2 \pm 2.8$ & 0.61 & 0.12 & 0.93 \\
\hline Hue angle (CIE $h^{o}$, graus) & $69.4 \pm 16.6$ & $76.0 \pm 3.6$ & $60.4 \pm 19.1$ & $78.9 \pm 4.8$ & $76.1 \pm 6.1$ & $75.3 \pm 3.5$ & $<0.01$ & 0.04 & 0.01 \\
\hline
\end{tabular}

$\mathrm{CONT}=$ control; $\mathrm{CH} 2=2 \%$ fat replaced by chia seed $\mathrm{CH} 4=4 \%$ fat replaced by chia seed; $\mathrm{CH} 8=8 \%$ fat replaced by chia seed.

${ }^{1}$ Significant probabilities $(P<0.05)$ were placed in bold.

${ }^{a-b}$ Means in the same row, into each effect, followed by different letters differ $(P<0.05)$. 




$74.7 \%$ of the variance in the data after fitting with a vector model and a coefficient of determination $\left(\mathrm{R}^{2}\right)$ of 0.9686 . NUNES et al., (2012) reported that at less $45 \%$ of variance in the data indicated that the model was adequate. Therefore, the present study achieved a better variance suitable to explain the main differences among samples.

There are three distinctive groups for sample-characteristics in accordance with the CATA analysis. Control group samples were reported by CATA questions as "seasoned", "tenderness", and with perceived "pleasant flavor" and "brown color" appearance. Conversely, $\mathrm{CH} 2$ and $\mathrm{CH} 4$ were grouped together throughout the attributes relating for "juicy", "fibrous", "salty", "grain texture", and perceived "bland flavor", "caramel flavor", "cooked flavor", and "bitter aftertaste", while treatment $\mathrm{CH} 8$ was described as "yellowness pale color", "crispy", "integrate texture", and "uniform appearance". It is suitable to affirm that the treatments $\mathrm{CH} 4$ and $\mathrm{CH} 8$ had lower scores acceptance may be due to the masked flavor with higher added chia seeds, mitigating the spicy taste (well perceived in control group samples, figure 2) and other flavor components formed in the products during the cooking process. The CATA analysis has also indicated the control group with "tenderness" texture, which can explain clearly an increasing of shear force in those samples with chia seeds added. Instrumental color measured in grilled burgers has not shown to be detrimental for the sensory appearance. Hence, sensory analysis results indicated that all samples had good acceptability with hedonic scores above than 7 (moderately liked). Concerning the shear force, which was similar between $\mathrm{CH} 4$ and $\mathrm{CH} 8$, was maybe weakly 
Table 4 - Means ( \pm standard deviations) of the acceptance scores given by the judges for the sensory attributes of burgers prepared with partial replacement of pork fat by chia seed.

\begin{tabular}{|c|c|c|c|c|c|}
\hline \multirow[t]{2}{*}{ Attribute } & \multicolumn{4}{|c|}{ 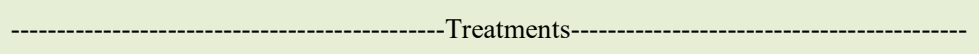 } & \multirow[t]{2}{*}{$\operatorname{Pr}>F^{1}$} \\
\hline & CONT & $\mathrm{CH} 2$ & $\mathrm{CH} 4$ & $\mathrm{CH} 8$ & \\
\hline Appearance & $7.6 \pm 1.5$ & $7.6 \pm 1.2$ & $7.3 \pm 1.3$ & $7.6 \pm 1.2$ & 0.36 \\
\hline Flavor & $8.3 \pm 1.2^{a}$ & $7.9 \pm 1.0^{a b}$ & $7.6 \pm 1.2^{a b}$ & $7.8 \pm 1.0^{b}$ & $<0.01$ \\
\hline Texture & $8.1 \pm 1.2$ & $8.0 \pm 0.9$ & $7.6 \pm 1.3$ & $7.8 \pm 1.0$ & 0.07 \\
\hline Overall impression & $8.1 \pm 1.2^{a}$ & $8.1 \pm 0.9^{a}$ & $7.6 \pm 1.2^{b}$ & $7.6 \pm 1.1^{b}$ & 0.01 \\
\hline
\end{tabular}

$\mathrm{CONT}=$ control; $\mathrm{CH} 2=2 \%$ fat replaced by chia seed $\mathrm{CH} 4=4 \%$ fat replaced by chia seed; $\mathrm{CH} 8=8 \%$ fat replaced by chia seed.

${ }^{1}$ Significant probabilities $(P<0.05)$ are placed in bold.

${ }^{\mathrm{a}-\mathrm{b}}$ Means with different superscripts within the same row for each characteristic differ significantly $(P<0.05)$.

perceived by the sensory panel as "fibrous" likely reported for $\mathrm{CH} 2$ and $\mathrm{CH} 4$, with the exception of those samples containing up to double added chia seeds (CH8). Either, CATA terms provided "pleasant flavor" for the control, but closely near of both $\mathrm{CH} 2$ and $\mathrm{CH} 4$. However, this concern could be attributed of the limitations of the CATA questions that they do not allow a direct measurement of the intensity of perceived attributes, which could potentially hamper discrimination between products that have similar sensory characteristics but differ slightly in the intensity of those characteristics (MEYNERS et al., 2016). According to ARES et al., (2015) the hedonic scales combined with CATA questions assessment compose the important tool for understanding consumer preference and to identify sensory attributes driving optimization of product formulation.

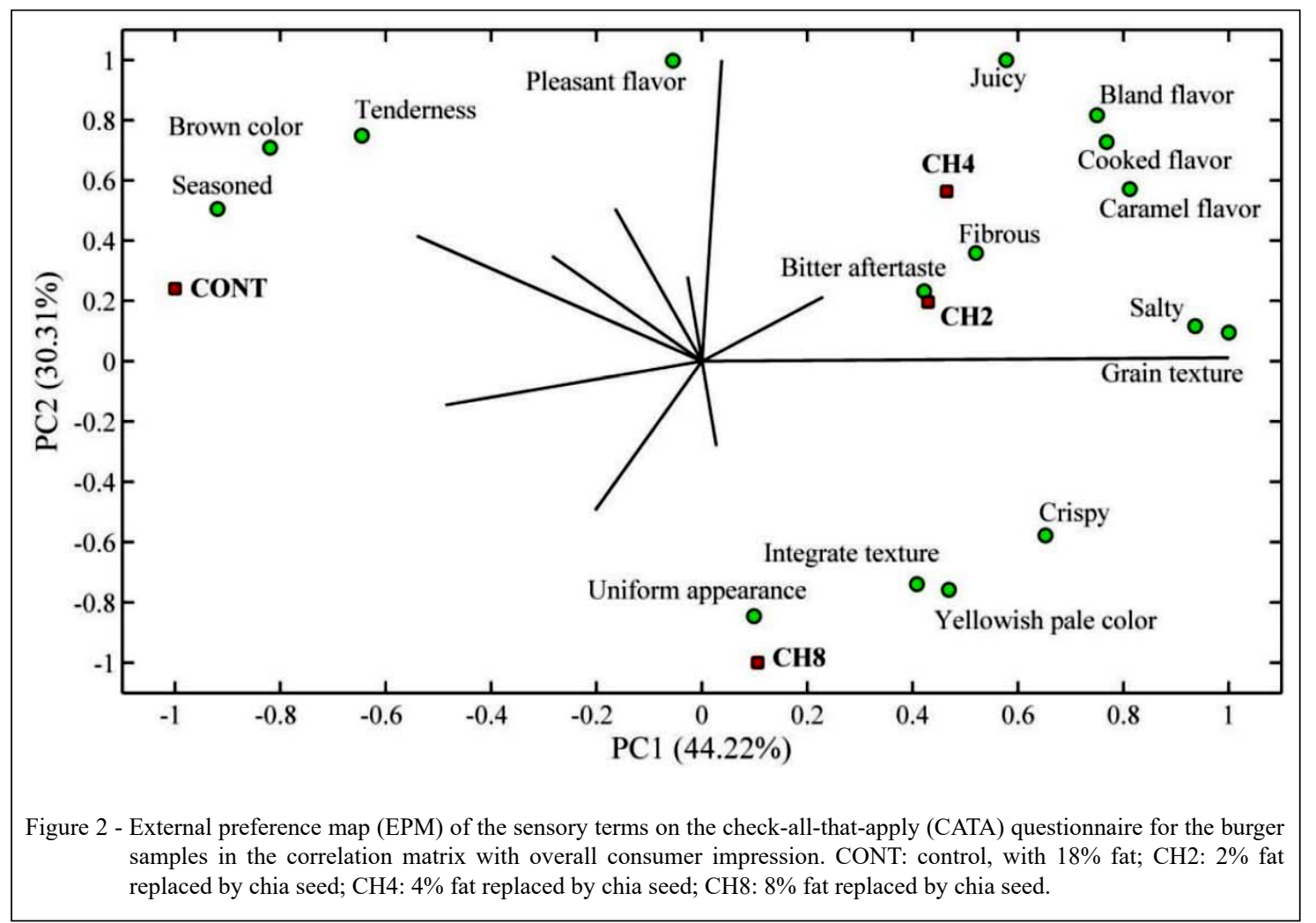

Ciência Rural, v.49, n.8, 2019. 


\section{CONCLUSIONS}

Chia seed additions as pork back fat replacer promoted small changes in technological characteristics of processed poultry burgers. Additionally, there was no great impact on the final acceptance of the burgers. Increasing chia seed content into producing burgers was effective in reducing the lipid oxidation, besides contributing to add dietary fibers to the product. Chia incorporation in grilled burgers appears to induce the fibrous, grain texture and crispy burgers texture. However, its uniformity and integrate texture allow to conclude that the replacement of pork back fat by chia seed, even up to $8 \%$, seems to be a technologically viable alternative for elaborating burgers, improving the nutritional value and "healthy" image of these products.

\section{ACKNOWLEDGEMENTS}

This study was financed in part by the and Coordenação de Aperfeiçoamento de Pessoal de Nível Superior (CAPES) for the scholarship grants to the first (Master Degree) author. The authors would like to thank also the Fundação de Amparo e Pesquisa de Minas Gerais (FAPEMIG) and the Conselho Nacional de Desenvolvimento Científico e Tecnológico (CNPq; $468775 / 2014-5)$ for the financial support.

\section{BIOETHICS AND BIOSSECURITY COMMITTEE APPROVAL}

Judgement number: 822.411. Date of report: 07-10-2014.

\section{DECLARATION OF CONFLICT OF INTERESTS}

The authors declare no conflict of interest. The founding sponsors had no role in the design of the study; in the collection, analyses, or interpretation of data; in the writing of the manuscript, and in the decision to publish the results.

\section{AUTHORS' CONTRIBUTIONS}

The authors contributed equally to the manuscript.

\section{REFERENCES}

ALFREDO, VO, et al. Physicochemical properties of a fibrous fraction from chia (Salvia hispanica L.). LWT - Food Science and Technology. v.42 (1), p.168-73, 2009. Available from: <https:// doi.org/10.1016/j.lwt.2008.05.012>. Accessed: Jan. 27, 2019. doi: 10.1016/j.lwt.2008.05.012.

ANVISA. Agencia Nacional de Vigilância Sanitária. Secretaria de Vigilância Sanitária (SVS). Resolução RDC no. 12, de 02 de janeiro de 2001. Aprova o Regulamento Técnico sobre padrões microbiológicos para alimentos. Diário Oficial [da] República Federativa do Brasil, Brasília, seção 1, p.11-E. 2001. Available from: <http://portal.anvisa.gov.br/documents/33880/2568070/ RDC 12 2001.pdf/15ffddf6-3767-4527-bfac-740a0400829b>. Accessed: Dec. 15, 2018.

ANVISA. Agência Nacional de Vigilância Sanitária (ANVISA). RDC no. 360, 23 de dezembro de 2003. Aprova o Regulamento Técnico sobre Rotulagem Nutricional de Alimentos Embalados. Brasilia. Diário Oficial [da] República Federativa do Brasil, seção 1, p.2. 2003. Available from: <http://portal.anvisa.gov.br/ documents/33880/2568070/res0360_23_12_2003.pdf/5d4fc7139c66-4512-b3c1-afee57e7d9bc>. Accessed: Dec. 15, 2018.

ANVISA. Agência Nacional de Vigilância Sanitária (ANVISA). RDC no. 54, 12 de novembro de 2012.Dispõe sobre o Regulamento Técnico sobre Informação Nutricional Complementar. Brasilia, Diário Oficial [da] República Federativa do Brasil, seção 1, p.4, 2012. Available from: $<$ http://portal.anvisa.gov.br/documents/ $\% 20$ 33880/2568070/rdc0054_12_11_2012.pdf/c5ac23fd-974e-4f2c9fbc-48f7e0a31864>. Accessed: Nov. 04, 2018.

AOAC.. Official methods of analysis of AOAC International. 19th ed. Gaithersburg, MD: Association of Official Analytical Chemists. 2012.

ARAÚJO, JM.. Química de Alimentos - Teoria e Prática. 5 Ed.: Editora UFV, Viçosa, Brazil. 2011.

ARES, G, JAEGER, SR.. Examination of sensory product characterization bias when check-all-that-apply (CATA) questions are used concurrently with hedonic assessments. Food Quality and Preference. v.40, p.199-208. 2015. Available from: <http:// doi.org/10.1016/j.foodqual.2014.10.004>. Accessed: Jan. 27, 2019. doi: 10.1016/j.foodqual.2014.10.004.

BRASIL.. Ministério da Agricultura, Pecuária e Abastecimento (MAPA). Secretaria de Defesa Agropecuária (SDA). Instrução Normativa no. 20, de 31 de julho de 2000. Aprova os Regulamentos Técnicos de Identidade e Qualidade de Almôndega, de Apresuntado, de Fiambre, de Hambúrguer, de Kibe, de Presunto Cozido e de Presunto. Brasilia, Diário Oficial [da] República Federativa do Brasil, seção 1, p.5. 2000. Available from: <http:// www.cfmv.org.br/portal/legislacao/outras_normas/instrucao_ normativa_020_MAA.htm>. Accessed: Feb. 02, 2019.

CARDOSO, GP, et al. Selection of a chitosan gelatin-based edible coating for color preservation of beef in retail display. Meat Science. v.114, p.85-94. 2016. Available from: $<$ https://doi. org/10.1016/j.meatsci.2015.12.012>. Accessed: Dec. 20, 2018. doi: 10.1016/j.meatsci.2015.12.012.

CAPITANI, MI, et al. Physicochemical and functional characterization of by-products from chia (Salvia hispanica L.) seeds of Argentina. LWT - Food Science and Technology. v.45, n.1, p.94-102. 2012 Available from: <https://doi.org/10.1016/j.lwt.2011.07.012>. Accessed: Jan. 29, 2019. doi: 10.1016/j.lwt.2011.07.012.

CHOI, YS, et al. Quality and Sensory Characteristics of Reducedfat Chicken Patties with Pork Back Fat Replaced by Dietary Fiber from Wheat Sprout. Korean Journal for Food Science of Animal Resources. v.36, p.799-806. 2016. Available from: $<$ https://doi. org/10.5851/kosfa.2016.36.6.799>. Accessed: Nov. 30, 2018. doi: 10.5851/kosfa.2016.36.6.799.

DING, Y, et al. Nutritional composition in the chia seed and its processing properties on restructured ham-like products. Journal of Food and Drug Analysis. v26, p. 124-34. 2018. Available from: 
<https://doi.org/10.1016/j.jfda.2016.12.012>. Accessed: Jan. 09, 2019. doi: $10.1016 /$ j.jfda.2016.12.012.

DOWNES, FP, ITO, K. Compendium of methods for the microbiological examination of foods. $4^{\text {th }}$ Edition. Amer Public Health Assn. Washington, DC, USA, 2001.

ELMORE, JR, et al. Preference mapping: relating acceptance of "creaminess" to a descriptive sensory map of a semi-solid. Food Quality and Preference, v.10, p.465-475, 1999. Available from: <https://doi.org/10.1016/S0950-3293(99)00046-4>. Accessed: Dec. 13, 2018. doi: 10.1016/S0950-3293(99)00046-4.

FERNANDES, S. S.; SALAS-MELLADO, MDLM. Addition of chia seed mucilage for reduction of fat content in bread and cakes. Food Chemistry, 227: 237-244, 2017. Available from: <https:// doi.org/10.1016/j.foodchem.2017.01.075>. Accessed: Jan. 22, 2019. doi: 10.1016/j.foodchem.2017.01.075.

IAL. Instituto Adolfo Lutz. Normas analiticas do instituto Adolfo Lutz. $5^{a}$ Ed ed. 2008.

JORGE, EC, et al. Application of a check-all-that-apply question for evaluating and characterizing meat products. Meat Science. v.100, p.124-33, 2015. Available from: <https://doi.org/10.1016/j. meatsci.2014.10.002>. Accessed: Dec. 15, 2018. doi: 10.1016/j. meatsci.2014.10.002

LÓPEZ-VARGAS, JH, et al. Quality characteristics of pork burger added with albedo-fiber powder obtained from yellow passion fruit (Passiflora edulis var. flavicarpa) co-products. Meat Science. v.97, p.270-6. 2014. Available from: <https://doi.org/10.1016/j meatsci.2014.02.010>. Accessed: Nov. 10, 2018. doi: 10.1016/j. meatsci.2014.02.010

MARINELI, RdS, et al. Chemical characterization and antioxidant potential of Chilean chia seeds and oil (Salvia hispanica L.). LWT - Food Science and Technology. v.59, p.1304-10, 2014. Available from: $<$ https://doi.org/10.1016/j.lwt.2014.04.014>. Accessed: Dec. 21, 2018. doi: 10.1016/j.lwt.2014.04.014.

MASSINGUE, AA, et al. Effect of mechanically deboned poultry meat content on technological properties and sensory characteristics of lamb and mutton sausages. Asian-Australas Journal of Animal Science, v.31(4), p.576-84, 2018. Available from: <https://doi.org/10.5713/ajas.17.0471>. Accessed: Jul. 22, 2018. doi: 10.5713/ajas.17.0471.

MEYNERS, M. On the analysis of Rate-All-That-Apply (RATA) data. Food Quality and Preference, v.49, p.1-10, 2016. Available from: <http://doi.org/10.1016/j.foodqual.2015.11.003>. Accessed: Dec. 15, 2018. doi: 10.1016/j.foodqual.2015.11.003.

MILLER, MF, et al. Physical and Sensory Characteristics of Low Fat Ground Beef Patties. J. Food Science, v.58 p.461-463, 1993. Available from: $<$ https://doi.org/10.1111/j.1365-2621.1993. tb04299.x>. Accessed: Dec. 15, 2018. doi: 10.1111/j.13652621.1993.tb04299.x.

MOHD ALI, N,. The Promising Future of Chia, Salvia hispanica L. Journal of Biomedicine and Biotechnology, v.2012 p.19,2012. Available from: <http://dx.doi.org/10.1155/2012/171956>. Accessed: Dec. 15, 2018. doi: 10.1155/2012/171956.

NUNES, CA, et al. Relating Consumer Acceptance to Descriptive Attributes by Three-Way External Preference Mapping Obtained by Parallel Factor Analysis (Parafac). Journal of Sensory Studies. v.27,p.209-16. 2012. Available from: <https://doi.org/10.1111/ j.1745-459X.2012.00387.x>. Accessed: Jan. 29, 2019. doi: 10.1111/j.1745-459X.2012.00387.x.

RAHARJO, S, et al. Improved speed, specificity, and limit of determination of an aqueous acid extraction thiobarbituric acid-C18 method for measuring lipid peroxidation in beef. J. Agric. Food Chemistry. v.40 p.2182-2185, 1992. Available from: $<$ http://dx.doi.org/10.1021/jf00023a027>. Accessed: Dec. 21, 2018. doi: $10.1021 / \mathrm{jf} 00023 \mathrm{a} 027$.

RAMOS, EM, GOMIDE, LAM. Avaliação da Qualidade de Carnes: Fundamentos e Metodologias. $2^{\text {a }}$ Ed. Editora UFV, Viçosa, Brazil, 2017.

REYES-CAUDILLO, E et al. Dietary fiber content and antioxidant activity of phenolic compounds present in Mexican chia (Salvia hispanica L.) seeds. Food Chemistry. v.107, p.656-63, 2008. Available from: <https://doi.org/10.1016/j.foodchem.2007.08.062>. Accessed: Jan. 14, 2019. doi: 10.1016/j.foodchem.2007.08.062.

RODRÍGUEZ-CARPENA, JG, et al. Avocado, sunflower and olive oils as replacers of pork back-fat in burger patties: Effect on lipid composition, oxidative stability and quality traits. Meat Science. v.90, p.106-115, 2012. Available from: <https://doi.org/10.1016/j. meatsci.2011.06.007>. Accessed: Nov. 29, 2018. doi: 10.1016/j. meatsci.2011.06.007.

SARGI, SC, et al. Antioxidant capacity and chemical composition in seeds rich in omega-3: chia, flax, and perilla. Food Science and Technology. v.33, p.541-8,2013. Available from: <http://dx.doi. org/10.1590/S0101-20612013005000057>. Accessed: Dec. 19, 2018. doi: $10.1590 / \mathrm{S} 0101-20612013005000057$.

SELANI, MM, et al. Effects of pineapple byproduct and canola oil as fat replacers on physicochemical and sensory qualities of low-fat beef burger. Meat Science. v.112, p.69-76, 2016. Available from: $<$ https://doi.org/10.1016/j.meatsci.2015.10.020>. Accessed: Nov. 29, 2018. doi: 10.1016/j.meatsci.2015.10.020.

SILVA, DRG, et al. Comparison of Warner-Bratzler shear force values between round and square cross-section cores from cooked beef and pork Longissimus muscle. Meat Science, v.103, p.1-6, 2015. Available from: <https://doi.org/10.1016/j. meatsci.2014.12.009>. Accessed: Jan. 07, 2019. doi: 10.1016/j. meatsci.2014.12.009.

SCAPIN, G., et al. Effect of chia seed (Salvia hispanica) as an antioxidant in fresh pork sausage. International Food Research Journal, v.22, n.3 p.1195-1202. 2015. Available from: <http:// www.ifrj.upm.edu.my $/ 22 \% 20(03) \% 202015 /(44)$.pdf $>$. Accessed: Jan. 13, 2019. doi: 22(3):1195-1202(2015).

TREVISAN, Y. C., et al. Efeito da adição de fibra de aveia sobre as propriedades físico-químicas de hambúrguer cozido $\mathrm{e}$ congelado com redução de gordura e sal. Brazilian Journal of Food Technology, v.19, e2015079, 2016. Available from: <http:/ dx.doi.org/10.1590/1981-6723.7915>. Accessed: Jan. 19, 2019. doi: 10.1590/1981-6723.7915.

YADAV, S, et al. Effect of wheat bran and dried carrot pomace addition on quality characteristics of chicken sausage. AsianAustralasian Journal of Animal Sciences, v.31, p.729-37, 2018. Available from: $<$ https://doi.org/10.5713/ajas.17.0214>. Accessed: Dec. 15, 2018. doi: 10.5713/ajas.17.021. 